\title{
Media Fun Thinkers Based on Calistug Questions
}

\author{
Jummita 1*, I Gusti Ayu Tri Agustiana 2*, I Ketut Dibia ${ }^{3 *}$ iD \\ 1,2,3 Pendidikan Guru Sekolah Dasar, Universitas Pendidikan Ganesha, Singaraja, Indonesia \\ *Corresponding author: jummita11@gmail.com
}

\section{Abstrak}

Penggunaan gadget secara terus menerus dapat memberikan dampak buruk bagi siswa. Hal tersebut berdampak pada pola perilaku dan aktivitas belajar siswa. Diperlukannya media penyeimbang dalam pembelajaran daring yaitu media yang bersifat konkret. Penelitian ini bertujuan untuk menciptakan media fun thinkers berbasis soal calistung yang dapat meningkatkan minat belajar siswa dan menyeimbangkan pembelajaran daring. Jenis penelitian ini yaitu penelitian pengembanga dengan menggunakan prosedur ADDIE. Subjek uji coba pada penelitian ini yaitu 2 orang ahli materi soal, 2 orang ahli media pembelajaran, 2 orang praktisi dan 7 orang siswa. Metode yang digunakan untuk mengumpulkan data pada penelitian ini adalah metode kuesioner. Instrumen pengumpulan data yang digunakan pada penelitian ini adalah rating scale. Teknik analisis data yang digunakan pada penelitian ini yaitu analisis data deskriptif kualitatif dan kuantitatif. Hasil penelitian yaitu hasil penilaian yang diberikan oleh ahli materi pelajaran memberikan penilaian 4,63 (sangat baik), ahli media pelajaran memberikan penilaian 4,82 (sangat baik), penilaian yang diberikan oleh ahli respon praktisi yaitu 4,85 (sangat baik) dan hasil uji respon siswa media yaitu 4,95 (sangat baik), hasil tersebut menunjukakan media fun thinkers berbasis soal calistung layak digunakan. Media fun thinkers berbasis soal calistung dapat digunakan dalam proses pembelajaran. Implikasi penilaian yaitu media pembelajaran ini dapat digunakan oleh guru dan dalam proses pembelajaran.

Kata kunci: Media Fun Thinkers, Calistung

\section{Abstract}

Continuous use of gadgets can hurt students. This has an impact on behaviour patterns and student learning activities. The need for balancing media in online learning is media that is concrete. This type of research is development research using the ADDIE procedure. The test subjects in this study were 2 subject matter experts, 2 learning media experts, 2 practitioners and 7 students. The method used to collect data in this study is the questionnaire. The data collection instrument used in this study was a rating scale. The data analysis technique used in this research is descriptive qualitative and quantitative data analysis. The results of the study are the results of the assessment given by subject matter experts assessing 4.63 (very good), learning media experts giving an assessment of 4.82 (very good), the assessment given by practitioner response experts is 4.85 (very good), and the results of the media student response test were 4.95 (very good). So media fun thinkers based on calistung questions can be used in the learning process. The assessment implies that this learning media can be used by teachers and in the learning process.

Keywords: Media Fun Thinkers, Calistung

\begin{tabular}{|c|c|c|}
\hline \multicolumn{2}{|l|}{ History: } & Publisher: Undiksha Press \\
\hline Received & : March 19, 2021 & Licensed: This work is licensed under \\
\hline Revised & : March 21, 2021 & a Creative Commons Attribution 3.0 License \\
\hline Accepted & : June 25, 2021 & लि (i) \\
\hline Published & : July 25, 2021 & (c) ${ }_{\mathrm{EY}} \mathrm{SA}_{\mathrm{SA}}$ \\
\hline
\end{tabular}

\section{Introduction}

Indonesia is currently being shocked by the disease outbreak caused by the coronavirus that can cause death (Dewi, 2020; Wahyono, Husamah, \& Budi, 2020). This has caused the government to anticipate the spread of COVID-19 by issuing social restrictions, working and studying from home (Alavudeen et al., 2021; Ayuni et al., 2021). This pandemic has an impact on all aspects of life, especially in the field of education. Currently, learning must be conducted online (Abidah, et al, 2020; Atmojo \& Nugroho, 2020). In online learning, of course, paying attention to provisions such as learning activities must create meaningful learning, not burden students, pay attention to conditions, consider learning facilities at home, and provide feedback to students (Atmojo \& Nugroho, 2020; Baber, 2021). The condition of online learning requires students to be able to learn independently. Online learning is very 
different from face-to-face learning in schools. Online learning emphasizes the readiness and accuracy of students in processing and receiving learning presented online by the teacher (Aji, 2020; Wardani et al., 2020). This causes students to have readiness in the online learning process, especially for elementary school children. Parental supervision and support are needed, which will make it easier for students to receive information when learning online (Ariebowo, 2021; Dewi, 2020; Wulandari \& Purwanta, 2021).

Today's problem is that some children use the facilities provided by their parents, such as cellphones, not to study, which will hurt children's behaviour patterns (Hendriawan \& Septian, 2019; Pebriana, 2017). Children will depend and become a necessity to use gadgets as a routine activity that must be done in everyday life (Ompi et al., 2020). Almost every child can use gadgets, especially when online learning is done online. It is better if the use of gadgets must be accompanied and supervised by parents so that the adverse effects of using gadgets can be minimized (Lilawati, 2020; Yulianingsih et al, 2020).

One of the things that cannot be denied as a result of the use of gadgets in children causes children to prefer playing with gadgets, lack of good interaction with friends and parents, reduced psychomotor abilities, difficulty in socializing, lack of interest in learning from children and difficulty adapting to the subject matter. (Kharisma Bismi Alrasheed \& Aprianti, 2011; Widiyono, 2020). Teachers must innovate to create a fun learning for students so that students do not get bored and attract students' attention so that they are not addicted to gadgets. In addition, teachers also need engaging learning media and can stimulate students' interest in learning. Based on the observations made at SD Cluster V, Buleleng District, it can be obtained when the online learning process is that the teacher only gives assignments to students. In addition, the lack of learning media that helps students learn independently also impacts students' common understanding.

The solution to overcome these problems is to develop innovative learning media that can improve students' understanding. Based on the results of distributing questionnaires to grade 1 teacher. $90 \%$ of teachers strongly agree to use learning media in teaching. $86 \%$ of teachers strongly agree with teaching teachers to use various learning media. $93 \%$ of teachers strongly agree that when using learning media, students are more enthusiastic about learning $93 \%$ strongly agree that the learning media is designed with learning while playing techniques to support thematic learning.

Learning media is a tool that can help students in learning (Afifah, 2019; Putra, Handarini, \& Ramli, 2019; Wiastuti, Suadnyana, \& Kristiantari, 2014). Concrete learning media will greatly support learning at home because it makes learning fun, meaningful, and avoids excessive gadgets and attracts students' learning attention (Indriyani et al., 2019; Purwanti, 2015). Concrete media are original media that can assist teachers in conveying information to school children. This learning media can be used in the learning process that will generate new interest, motivation, and have an impact on students' psychology (Hadiyati \& Wijayanti, 2017; Khairunnisa \& Ilmi, 2020).

One of the media that teachers can use during the Covid-19 pandemic is media fun thinkers. Fun thinkers learning media is designed in match frames accompanied by blocks with numbers and colours behind the blocks. This media is also equipped with a book, and there is an unlucky sheet and the answer: Left and right sides for answer sheets. The question sheets and answers are given related to thematic learning. The characteristics of this media contain level 10 material containing English and mathematics questions, but what is developed in this research is a calistung-based question suitable for elementary school students to make it easier for students to learn essential learning such as reading, writing, and arithmetic. The pillar of thematic learning is calistung which is believed to improve and grow students' systematic and logical thinking skills (Mulyadin, 2016; Ruiyat et al., 2019; Safitri et al., 2018). The findings of previous research stated that concrete media could make it easier 
for students to understand learning materials (Arianti et al., 2019a; Sutama et al., 2017). Other research findings also state that concrete media can increase student enthusiasm and learning outcomes (Arianti et al., 2019a; Hadiyati \& Wijayanti, 2017). There is no study on media fun thinkers based on calistung questions because, in general, the media contains exercises in mathematics and English.

Media fun thinkers based on calistung questions were developed based on the material from the teacher's and grade 1 students' books on the theme of 7 objects, animals, and plants around me. This media consists of books and props in the form of match frames accompanied by small blocks measuring $4 \mathrm{x} 4 \mathrm{~cm}$. This media consists of front and back covers, instructions for use, table of contents, basic competencies and indicators, media content section which contains practice questions. The paper used in this fun thinkers media is A3 size paper and is divided into two, namely A4 on the left side of the sheet in the form of questions and the right side of the answer sheet. The advantages of this fun thinkers media were developed differently from the fun thinkers media as in general with the characteristics of the questions containing calistung-based question material so that it makes it easier for students to study theme books, hone calistung skills, make learning more meaningful, arouse student interest in learning because students are given direct learning. The purpose of this research is to create media for fun thinkers based on calistung questions that can improve basic learning skills (reading, writing and arithmetic). It is hoped that this learning media can help students in learning so that they can improve students' understanding and calistung abilities.

\section{Methods}

This type of research is development research. The procedure used in this study is the ADDIE model, which includes the stages of analysis, design, development, implementation, and evaluation (Rosmiati, 2019). The research development design is presented in Figure 1.

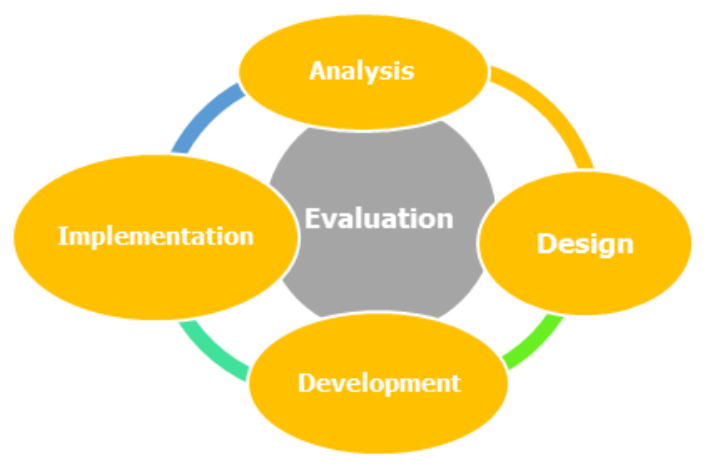

Figure 1. Research design with ADDIE Model (Suryadi et al., 2020)

The test subjects in this study were 2 subject matter experts, 2 learning media experts, 2 practitioners and 7 students. The methods used to collect data in this study were observation and questionnaires. The observation method is done to collect data about the problems that are happening at school. The questionnaire method was used to collect data from the assessment results given by experts regarding the developed media. The data collection instrument used in this study was a rating scale. This instrument is used to obtain quantitative data (numbers/scores), which can then be described qualitatively. The instrument grid is presented in table 1 , table 2 , table 3 and table 4. 
Table 1. Grid of Expert Validation Sheets for Media Questions Fun Thinkers

\begin{tabular}{|c|c|c|c|}
\hline No & Aspect & & Indicator \\
\hline 1 & Language Usage & & $\begin{array}{l}\text { Quality of language preparation } \\
\text { Quality of sentence usage }\end{array}$ \\
\hline 2 & Contents & & $\begin{array}{l}\text { The relevance of the question material to basic competencies } \\
\text { The relevance of the question material to the indicators } \\
\text { The relevance of the question material to the level of student } \\
\text { development } \\
\text { The relevance of the question material to the charge of } \\
\text { calistung }\end{array}$ \\
\hline 3 & $\begin{array}{l}\text { Presentation } \\
\text { questions }\end{array}$ & of & $\begin{array}{l}\text { Question display } \\
\text { Truth about }\end{array}$ \\
\hline
\end{tabular}

(Ma'ratusholihah et al., 2019)

Table 2. Media Fun Thinkers Media Expert Validation Instrument Grid

\begin{tabular}{|c|c|c|}
\hline No & Aspect & Indicator \\
\hline \multirow{4}{*}{1} & & cover design \\
\hline & Media Design & Presentation of the displayed image \\
\hline & & Displayed text presentation \\
\hline & & Display color presentation \\
\hline 2 & Language Usage & Quality of language use \\
\hline 3 & Ease of Use & Ease of use of media \\
\hline
\end{tabular}

(Mapicayanti et al., 2018)

Table 3. Practitioner Response Instrumental Grid to Media Fun Thinkers

\begin{tabular}{cll}
\hline No & \multicolumn{1}{c}{ Aspect } & \multicolumn{1}{c}{ Indicator } \\
\hline 1 & Appearance & Media display quality \\
2 & Language & Quality of language use \\
3 & Contents & Media content quality \\
4 & Media survival & Media survival \\
5 & Ease of Use of Media & Ease of use of media \\
\hline
\end{tabular}

Table 4. Grid of Student Response Instruments to Media Fun Thinkers

\begin{tabular}{lll}
\hline No & \multicolumn{1}{c}{ Aspect } & \multicolumn{1}{c}{ Indicator } \\
\hline 1 & Appearance & The attractiveness of the media display \\
2 & Language & Ease of use of language \\
3 & Contents & The quality of the content of the question \\
& & material \\
4 & Ease of Use of Media & Ease of use of media \\
\hline
\end{tabular}

(Baiduri et al., 2019)

Content validity is used to determine the level of validity of the media instrument grid that is compiled. This validity test was carried out using the Gregory formula. This reliability test is implemented by assessing two experts (judges) by the field-tested. The formula that 
can be used for reliability testing is the percentage of agreement. The data analysis technique used in this research is descriptive qualitative and quantitative data analysis. The descriptive qualitative analysis comes from the results of reviews from experts in the form of criticism, feedback, and suggestions on the developed learning media. Quantitative descriptive analysis was used to analyze product trials' assessment (score) using the mean and percentage of agreement formulas.

\section{Results and Discussion Results}

This research was conducted using the ADDIE model, a development research model consisting of several stages that can be used to design and develop a training program effectively and efficiently. The first stage is analysis. This research was conducted with four analysis steps, namely curriculum analysis, student characteristics, needs and media. Based on the results of the needs analysis, there is a need for a learning media that supports thematic learning to support the learning process in the classroom and at home. The results of the curriculum analysis are compiling indicators of achievement of essential competencies, materials and learning objectives to be achieved. The curriculum analysis carried out can be used as a guide in developing media for fun thinkers based on calistung questions. The analysis of student characteristics shows that children at the age of 7-11 years or elementary school-age experience a concrete operational stage I, which requires learning with things that are concrete, natural and can be observed directly by students. Based on the media analysis results, good criteria can be seen from the media's effectiveness, efficiency, and communicativeness.

The second stage designs. At this stage, it is done by compiling media instruments and a design for developing media for fun thinkers based on calistung questions. In addition, at this stage, the Researcher designed a media for fun thinkers based on calistung questions, which was developed with material guidelines for teachers' and grade 1 students' books on the theme of 7 objects, animals and plants. Media fun thinkers based on calistung questions are intended for grade 1 elementary school students. The software used to design this media is the Corel Draw X7 application for designing layouts and Photoshop for editing images. The design of this media starts from designing the front and back covers for the media fun thinkers, compiling questions based on essential competencies, materials, indicators, and objectives to be achieved in the content of the media fun thinkers book and designing the content display design for the media fun thinkers. The paper used in designing this fun thinkers media is A3 size paper divided into two, namely A4 on the left side in the form of questions and the right side with answers. Media is presented in hardcopy and complete with props. The results of the media design are presented in Figure 1.

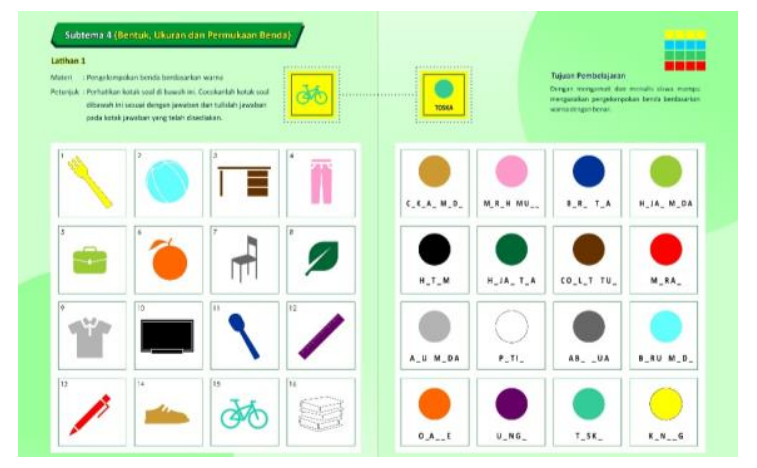

Figure 1. Media Fun Thinkers . Design 
The third stage is development. The implementation of the development stage is carried out by developing the actual product by the results of the analysis and design. This fun thinkers media cover is designed with a green background with pictures that match the grade 1 students' books on the theme of 7 objects, animals and plants. The font size used adjusts to the size of the cover so that it looks easy to read. The results of the products developed are presented in Figure 2.
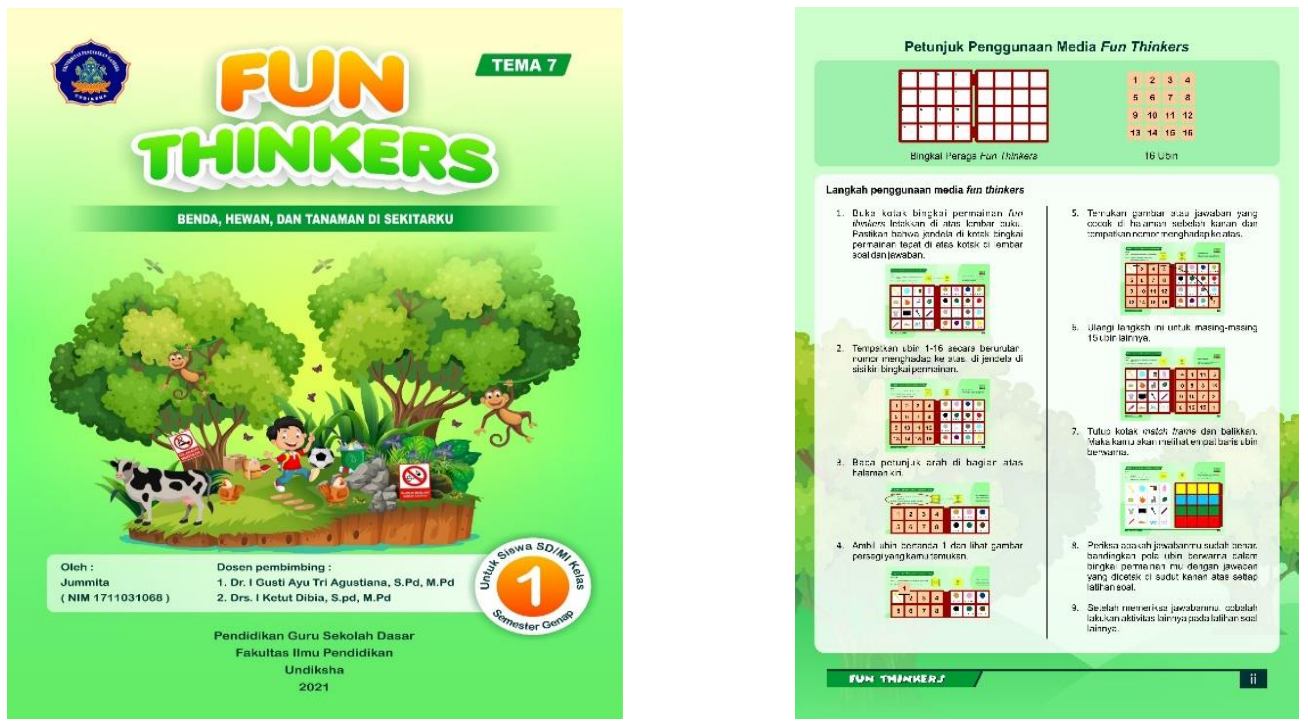

Figure 2. Results of the Development of Media Fun Thinkers

After the Fun Thinkers media based on calistung questions was developed, an assessment of the product was carried out by experts and practitioners and students to determine the validity of the developed media. In addition, this assessment is carried out to obtain comments in the form of suggestions and criticisms to improve the developed media so that the media becomes a suitable medium for the learning process. Based on the assessment results given by the subject matter experts, the developed media got a value of 4.63, so that it got an excellent category. The assessment results given by instructional media experts, the media developed got a value of 4.82 , so it got an excellent category. The assessment results given by the practitioner's response, the developed media got a value of 4.85 , so it got an excellent category. The assessment results given by the student response test of the developed media got a value of 4.95 , which got an excellent category. The suggestions given by the experts to improve the product of media fun thinkers based on calistung questions that have been developed are; give space between letter distinctions with spaces and without spaces, and provide examples of images that are easily recognizable by students.

Based on the results of data analysis, it can be concluded that the product of media fun thinkers based on calistung questions gets an excellent category so that it is feasible to be applied in the learning process. The developed media is developed by the needs analysis that has been carried out. Based on the needs analysis conducted to determine the needs of teachers and students in the learning process, questionnaires were distributed to grade 1 teacher at SD Gugus V, Buleleng District regarding media development. The results showed that teachers strongly agreed to develop media fun thinkers based on calistung questions that would be used. Can support the thematic learning process and learning that is done at home and in the classroom. Therefore, media fun thinkers based on calistung questions were developed to help teachers and students in the learning process. This media will also make it easier for students to understand the learning material to impact student learning outcomes. 


\section{Discussion}

Fun Thinkers Learning Media based on calistung questions is feasible to be applied in the learning process due to several factors, namely as follows. First, fun thinkers learning media based on calistung questions can be applied in the learning process because it can stimulate students' willingness to learn. Media Fun Thinkers based on calistung questions developed to attract students' interest and attention. It is due to the excellent display quality of the media. Attractive media displays can increase students' enthusiasm for learning (Hosen et al., 2021; Prasasti et al., 2019). In addition, this media also uses good quality language to make it easier for students to learn. Good language quality will make students more stimulated and increase student interest in learning (Herawati \& Muhtadi, 2018; Lee \& Osman, 2012; Neppala et al., 2018; Sidiq \& Najuah, 2020).

The ease of using this media can also increase students' enthusiasm for learning. This learning media is designed in a matching frame accompanied by blocks containing colours and numbers behind the blocks to increase student interest in learning. Media Fun Thinkers has fun elements in games so that students do not get bored in learning. Learning while playing will make students feel happy and motivated to learn (Nurani \& Mayangasri, 2017; Puspitasari \& Murda, 2018; Utomo et al., 2018). Media fun thinkers are equipped with a book that already contains direct instructions, making it easier for students to use it. This learning media can also emphasize the active involvement of students in the learning process so that they can train children and find their knowledge. Development of creativity and innovation to create media for fun thinkers based on calistung questions in grade 1 SD with a theme of 7 objects. Animals and plants will facilitate essential learning (reading, writing and arithmetic) in thematic learning and balancing online or distance learning so that students do not only rely on Information Technology media through gadget support tools and make learning at home more fun.

Second, fun thinkers learning media based on calistung questions is feasible in the learning process because it makes it easier for students to understand the subject matter. Media fun thinkers are media that are real and concrete. Concrete learning media will make it easier for students to understand the material presented in the media (Arianti et al., 2019b; Carlucy et al., 2018). Concrete learning media can also help teachers explain learning materials (Arianti et al., 2019b; Sutama et al., 2017). It is by Piaget's theory, which states that children aged 7-11 years or elementary school-age experience a concrete operational stage I which requires learning through experience with things that are concrete, natural and can be observed directly by students (Carlucy et al., 2018; Prabaningrum \& Putra, 2019). Media fun thinkers based on calistung questions can make it easier for students to learn essential learning, namely reading, writing, and arithmetic which is believed to improve students' logical and thematic thinking skills, improve students' skills in reflecting their thoughts and ideas. Students who can read, write and count well will tend to understand better and be able to follow the lesson well.

The findings of previous research stated that learning media could improve students' understanding of the subject matter (Fatmawati \& Harmanto, 2019; Linda et al., 2018; Primasari, 2014). Other research findings also state that the use of learning media can improve student learning outcomes (Dewi, Kristiantari, \& Ganing, 2019; Hanifah \& Budiman, 2019; Putra \& Sujana, 2020). The advantages of this fun thinkers media developed are different from the fun thinkers media as in general, with the characteristics of the questions containing English and math problem material. Because the fun thinkers media developed is based on calistung questions for elementary school students in grade 1 on the theme of 7 objects, animals and plants. This research contributes to increasing students' enthusiasm for learning. The limitation of this study is that this study was only conducted in small group trials due to the Covid-19 pandemic. Future research is expected to be able to 
continue this research through experiments with more students. This research implies that teachers and students can use media fun thinkers based on calistung questions for elementary school students in grade 1 on the theme of 7 objects in the learning process. This media will help teachers deliver material, help students learn and hone essential reading, writing, and arithmetic skills, while also making it easier for students to understand the material by learning while playing.

\section{Conclusion}

The media fun thinkers based on calistung questions developed an excellent category so that they could and deserve to be used in the learning process. It is recommended that teachers use media fun thinkers based on calistung questions because it can help students learn and hone essential skills.

\section{References}

Abidah, A., Hidaayatullaah, H. N., Simamora, R. M., Fehabutar, D., \& Mutakinati, L. (2020). The Impact of Covid-19 to Indonesian Education and Its Relation to the Philosophy of "Merdeka Belajar." Studies in Philosophy of Science and Education, 1(1), 38-49. https://doi.org/10.46627/sipose.v1i1.9

Afifah, N. (2019). Efektivitas Media Ajar untuk Siswa Kelas Rendah Berbasis Nilai Karakter Toleransi terhadap Sesama dengan Berbantu Aplikasi Sparkol Videoscribe. Modeling: Jurnal Program Studi PGMI, 6(2). https://doi.org/10.36835/modeling.v6i2.512

Aji, R. H. S. (2020). Dampak Covid-19 pada Pendidikan di Indonesia: Sekolah, Keterampilan, dan Proses Pembelajaran $\square$ Dampak Covid-19 pada Pendidikan di Indonesia: Sekolah, Keterampilan, dan Proses Pembelajaran. Jurnal Sosial \& Budaya Syar-I, 5(1), 395-402. https://doi.org/10.15408/sjsbs.v7i5.15314

Alavudeen, S. S., Easwaran, V., Mir, J. I., Shahrani, S. M., Ahmed Mohammed Almodeer Aseeri, A. A., Khan, N. A., \& Asiri, A. A. (2021). The influence of COVID-19 related psychological and demographic variables on the effectiveness of e-learning among health care students in the southern region of Saudi Arabia. Saudi Pharmaceutical Journal. https://doi.org/10.1016/j.jsps.2021.05.009

Arianti, Wiarta, \& Darsana. (2019a). Pengaruh Model Pembelajaran Problem Posing Berbantuan Media Semi Konkret terhadap Kompetensi Pengetahuan Matematika. Jurnal Ilmiah Sekolah Dasar Undiksha, 3(4). https://doi.org/10.23887/jisd.v3i4.21765

Arianti, Wiarta, \& Darsana. (2019b). Pengaruh Model Pembelajaran Problem Posing Berbantuan Media Semi Konkret terhadap Kompetensi Pengetahuan Matematika. Jurnal Ilmiah Sekolah Dasar, 3(4). https://doi.org/10.23887/jisd.v3i4.21765

Ariebowo, T. (2021). Autonomous learning during COVID-19 pandemic: Students , objectives and preferences. Journal of Foreign Language Teaching and Learning, 6(1), 56-77. https://doi.org/10.18196/ftl.v6i1.10079

Atmojo, A. E. P., \& Nugroho, A. (2020). EFL classes must go online! Teaching activities and challenges during COVID-19 pandemic in Indonesia. Register Journal, 13(1), 49-76. https://doi.org/10.18326/rgt.v13i1.49-76

Ayuni, D., Marini, T., Fauziddin, M., \& Pahrul, Y. (2021). Kesiapan Guru TK Menghadapi Pembelajaran Daring Masa Pandemi Covid-19. Jurnal Obsesi : Jurnal Pendidikan Anak Usia Dini, 5(1). https://doi.org/10.31004/obsesi.v5i1.579

Baber, H. (2021). Modelling the acceptance of e-learning during the pandemic of COVID-19A study of South Korea. The International Journal of Management Education, 19(2). https://doi.org/10.1016/j.ijme.2021.100503

Baiduri, Marhan, \& Lufita. (2019). Pengembangan media pembelajaran pop-up book berbasis 
audio pada materi bangun datar segiempat. Jurnal Program Studi Pendidikan Matematika, 8(1). https://doi.org/10.24127/ajpm.v8i1.1951

Carlucy, Suadnyana, \& Negara. (2018). Pengaruh Model Pembelajaran Inkuiri Terbimbing Berbantuan Media Konkret Terhadap Kompetensi Pengetahuan IPA. Mimbar Ilmu Undiksha, 23(2), 162-169. https://doi.org/10.23887/mi.v23i2.16416

Dewi, N. N. K., Kristiantari, M. . R., \& Ganing, N. N. (2019). Pengaruh Model Pembelajaran Picture And Picture Berbantuan Media Visual Terhadap Keterampilan Menulis Bahasa $\begin{array}{llll}\text { Indonesia. Journal of Education } & \text { Technology, }\end{array}$ https://doi.org/10.23887/jet.v3i4.22364

Dewi, W. A. F. (2020). Dampak Covid-19 Terhadap Implementasi Pembelajaran Daring Di Sekolah Dasar. Jurnal Ilmu Pendidikan, 2(1). https://doi.org/10.31004/edukatif.vi1.89.

Fatmawati, F., \& Harmanto. (2019). Pengembangan Media Puzzle Berbasis Index Card Match Materi Peristiwa Lahirnya Pancasila Muatan IPS. Joyful Learning Journal 8, 8(2), 113-118. https://journal.unnes.ac.id/sju/index.php/jlj/article/view/31057

Hadiyati, N., \& Wijayanti, A. (2017). Keefektifan Metode Eksperimen Berbantu Media Benda Konkret Terhadap Hasil Belajar IPA Siswa Kelas V Sekolah Dasar. JIPVA (Jurnal Pendidikan IPA Veteran), 1(1). https://doi.org/10.31331/jipva.v1i1.513

Hendriawan, M. A., \& Septian, A. (2019). Pengembangan JiMath Sebagai Multimedia Pembelajaran Matematika Berbasis Android Untuk Siswa Sekolah Menengah Atas. IndoMath: $\quad$ Indonesia Mathematics 45. https://doi.org/10.30738/indomath.v2i1.2785

Herawati, N. S., \& Muhtadi, A. (2018). Pengembangan Modul Elektronik (E-Modul) Interaktif Pada Mata Pelajaran Kimia kelas XI SMA. Jurnal Inovasi Teknologi Pendidikan, 5(2), 180-191. https://doi.org/10.21831/jitp.v5i2.15424

Hosen, M., Ogbeibu, S., Giridharan, B., Cham, T.-H., Lim, W. M., \& Paul, J. (2021). Individual motivation and social media influence on student knowledge sharing and learning performance: Evidence from an emerging economy. Computers \& Education, 72. https://doi.org/10.1016/j.compedu.2021.104262

Indriyani, D., Mawardi, M., \& Wardani, K. W. (2019). Peningkatan Keterampilan Berpikir Kritis Melalui Model Inkuiri Berbantuan Media Konkret Pada Siswa Kelas 5 SD Negeri Mangunsari 05 Tahun Pelajaran 2018/2019. Jurnal Basicedu, 3(1). https://doi.org/10.31004/basicedu.v3i1.74

Khairunnisa, G. F., \& Ilmi, Y. I. N. (2020). Media Pembelajaran Matematika Konkret Versus Digital: Systematic Literature Review di Era Revolusi Industri 4.0. Jurnal Tadris Matematika, 3(2). https://doi.org/10.21274/jtm.2020.3.2.131-140

Kharisma Bismi Alrasheed, \& Aprianti, M. (2011). Hubungan Antara Kecanduan Gadget Dengan Kecerdasan Emosi Pada Remaja (Sebuah Studi Pada Siswa Smp Di Kecamatan Setiabudi Jakarta Selatan). Jurnal Sains Psikologi, 7(2), 136-142. https://doi.org/10.17977/um023v7i22018p136

Lee, T. T., \& Osman, K. (2012). Interactive Multimedia Module in the Learning of Electrochemistry: Effects on Students' Understanding and Motivation. Procedia - Social and Behavioral Sciences, 46. https://doi.org/10.1016/j.sbspro.2012.05.295

Lilawati, A. (2020). Peran Orang Tua dalam Mendukung Kegiatan Pembelajaran di Rumah pada Masa Pandemi. Jurnal Obsesi: Jurnal Pendidikan Anak Usia Dini, 5(1), 549. https://doi.org/10.31004/obsesi.v5i1.630

Linda, Albeta, Masnaini, \& Sulismawati. (2018). The Effect Of Prezy And Exe-Learning Media On Chemical Learning Results. Jurnal Edusains, 10(1). https://doi.org/10.15408/es.v10i1.7204.

Ma'ratusholihah, Priyanto, \& Damayani, A. . (2019). Pengembangan media pembelajaran tematik ular tangga berbagai pekerjaan. Mimbar PGSD Undiksha, 7(3). 
https://doi.org/10.23887/jjpgsd.v7i3.19411

Mapicayanti, Jamaludin, \& Ahmad, F. (2018). Perancangan media pembelajaran berbasis video tutorial mendesain jaringan lokal/LAN kelas $\mathrm{X}$ TKJ. Jurnal Pendidikan Informatika, $2(2)$. https://ejournal.hamzanwadi.ac.id/index.php/edumatic/article/view/913

Mulyadin. (2016). Implementasi Kebijakan Pembelajaran Tematik Terpadu Kurikulum 2013 Di SDN Kauman 1 Malang Dan Sd Muhammadiyah 1 Malang. Jurnal Pendidikan Edutama, 3(2), 31 - 48. https://doi.org/10.30734/jpe.v3i2.35

Neppala, P., Sherer, M. V., Larson, G., Bryant, A. K., Panjwani, N., Murphy, J. D., \& Gillespie, E. F. (2018). An Interactive Contouring Module Improves Engagement and Interest in Radiation Oncology Among Preclinical Medical Students: Results of a Randomized Trial. Practical Radiation Oncology, 8(4), e190-e198. https://doi.org/10.1016/j.pro.2018.01.001

Nur Millati Hanifah, M. A. K. B. M. A. B. (2019). Pengaruh Model Open Ended Problem Berbantu Media Kotak Telur Pelangi ( Kotela ) Terhadap Hasil Belajar. Journal of Education Technology., 3(3), 1-137. https://doi.org/10.23887/jet.v3i3.21734

Nurani, Y., \& Mayangasri, T. (2017). Pengembangan Model Kegiatan Sentra Bermain Dalam Mengembangkan Kreativitas Anak Usia Dini. Jurnal Pendidikan Usia Dini, 11(2). https://doi.org/10.21009/JPUD.112.15

Ompi, Sompie, \& Sugiarso. (2020). Video animasi interaktif 3d dampak penggunaan gadget pada anak sekolah dasar tingkat awal. Jurnal Teknik Elektro Dan Komputer, 9(2). https://doi.org/10.35793/jtek.9.2.2020.29717

Pebriana, P. H. (2017). Analisis Penggunaan Gadget Terhadap Kemampuan Interaksi Sosial Anak Usia Dini. Jurnal Obsesi: Journal of Early Childhood Education, 1(1). https://doi.org/10.31004/obsesi.v1i1.26

Prabaningrum, \& Putra. (2019). Pengaruh Model Pembelajaran Kooperatif Team Assisted Individualization Berbantuan Media Semi Konkret Terhadap Kompetensi Pengetahuan Matematika. Jurnal Ilmiah Sekolah Dasar, 3(4), 414. https://doi.org/10.23887/jisd.v3i4.21775

Prasasti, T. I., Solin, M., \& Hadi, W. (2019). The Effectiveness of Learning Media Folklore Text of North Sumatera Based on Blended Learning by 10th Grade Students of Vocational High SchoolHarapan Mekar-1 Medan. Bir-Le Journal, 4(2). https://doi.org/10.33258/birle.v2i4.548

Primasari, R. (2014). Penggunaan Media Pembelajaran di Madrasa Aliyah Negeri Se-Jakarta Selatan. Edusains, 6(1), 68-72. https://doi.org/10.15408/es.v6i1.1101

Purwanti, K. L. (2015). Pembelajaran Perkalian Pecahan Biasa Berbantu Media Benda Konkret: Studi Kasus Perbedaan Gender Terhadap Kemampuan Matematika Siswa Kelas V SDN Sambiroto 3 Semarang. Sawwa: Jurnal Studi Gender, 5(2). https://doi.org/10.21580/sa.v10i2.1431

Puspitasari, \& Murda. (2018). Pengaruh Model Pembelajaran IOC Berbantuan Media Audio Visual terhadap Hasil Belajar IPS. Mimbar PGSD Undiksha, 6(2). https://doi.org/10.23887/jjpgsd.v6i2.19470

Putra, A. T., Handarini, D. M., \& Ramli, M. (2019). Media Wayang Golek untuk Menumbuhkan Kesadaran Menyelesaikan Konflik secara Konstruktif bagi Siswa SMP. Jurnal Pendidikan: Teori, Penelitian, Dan Pengembangan, 4(11). https://doi.org/10.17977/jptpp.v4i11.13006

Putra, I. G. D., \& Sujana. (2020). Hasil belajar IPS menggunakan Kolaborasi Model Discovery Learning Berbasis Media Animasi. Journal of Educational Technology, 4, 103-109. https://doi.org/10.23887/jet.v4i2.25099

Rosmiati, M. (2019). Animasi Interaktif Sebagai Media Pembelajaran Bahasa Inggris 
Menggunakan Metode ADDIE. Paradigma: Jurnal Komputer Dan Informatika Univiersitas Bina Sarana Informatika, 21(2). https://doi.org/10.31294/p.v21i2.6019

Ruiyat, S. A., Yufiarti, Y., \& Karnadi, K. (2019). Peningkatan Keterampilan Berbicara dengan Bercerita Menggunakan Komik Elektronik Tematik. Jurnal Obsesi : Jurnal Pendidikan Anak Usia Dini, 3(2). https://doi.org/10.31004/obsesi.v3i2.256

Safitri, R. W., Primiani, C. N., \& Hartini, H. (2018). Pengembangan Media Flashcard Tematik Berbasis Permainan Tradisional Untuk Kelas IV Sub Tema Lingkungan Tempat Tinggalku. Pendidikan Dasar Dan Pembelajaran, 8(1), 11. https://doi.org/10.25273/pe.v8i1.1332

Sidiq, R., \& Najuah. (2020). Pengembangan E-Modul Interaktif Berbasis Android Pada Mata Kuliah Strategi Belajar Mengajar. Jurnal Pendidikan Sejarah, 9(1), 1-14. https://doi.org/10.21009/JPS.091.01

Suastika, I. K., \& Amaylyla. (2019). Pengembangan modul pembelajaran matematika dengan pendekatan kontekstual. Jurnal Pendidikan Matematika Indonesia, 4(2). https://doi.org/10.26737/jpmi.v4i2.1230

Suryadi, I., Yanto, Y., \& Mandasari, N. (2020). Pengembangan Media Pembelajaran Interaktif Berbasis Pmri Menggunakan Macromedia Flash Profesional 8. Judika Education, 3(2), 40-49. https://doi.org/10.31539/judika.v3i1.1263

Sutama, I. P. E., Dibia, I. K., \& Margunayasa, I. G. (2017). Pengaruh Model Pembelajaran Think Pair Share (Tps) Berbantuan Media Konkret Terhadap Hasil Belajar IPA. Mimbar PGSD Undiksha, 5. https://doi.org/10.23887/jjpgsd.v5i2.10683

Utomo, I. A., Ramli, M., \& Furaidah, F. (2018). Penerapan Strategi Bermain melalui Media Busy Book untuk Meningkatkan Fisik Motorik Halus Anak Usia Dini. Jurnal Pendidikan: Teori, Penelitian, Dan Pengembangan, 3(12). http://journal.um.ac.id/index.php/jptpp/article/view/12553

Wahyono, P., Husamah, H., \& Budi, A. S. (2020). Guru profesional di masa pandemi COVID-19: Review implementasi, tantangan, dan solusi pembelajaran daring. Jurnal Pendidikan Profesi Guru, 1(1), 51-65. https://ejournal.umm.ac.id/index.php/jppg/article/view/12462

Wardani, Anita, \& Ayriza, Y. (2020). Analisis Kendala Orangtua dalam Mendampingi Anak Belajar di Rumah Pada Masa Pandemi Covid-19. Jurnal Pendidikan Anak Usia Dini, 5(1). https://doi.org/10.31004/obsesi.v5i1.705.

Wiastuti, Suadnyana, \& Kristiantari. (2014). Pengaruh Pembelajaran Siklus Belajar (Learning Cycle) Berbantuan Media Audio Visual Terhadap Hasil Belajar Ipa Siswa Kelas V Sd Gugus Budi Utomo. Mimbar PGSD Undiksha, 2(1). https://doi.org/10.23887/jjpgsd.v2i1.2147

Widiyono, A. (2020). Efektifitas Perkuliahan Daring (Online) pada Mahasiswa PGSD di Saat Pandemi Covid 19. Jurnal Pendidikan, 8(2), 169-177. https://doi.org/10.36232/pendidikan.v8i2.458

Wulandari, H., \& Purwanta, E. (2021). Pencapaian Perkembangan Anak Usia Dini di Taman Kanak-kanak selama Pembelajaran Daring di Masa Pandemi Covid-19. Jurnal Obsesi : Jurnal Pendidikan Anak Usia Dini, 5(1). https://doi.org/10.31004/obsesi.v5i1.626

Yulianingsih, W., Suhanadji, S., Nugroho, R., \& Mustakim, M. (2020). Keterlibatan Orangtua dalam Pendampingan Belajar Anak selama Masa Pandemi Covid-19. Jurnal Obsesi: Jurnal Pendidikan Anak Usia Dini, 5(2), 1138-1150. https://doi.org/10.31004/obsesi.v5i2.740 